Salicylate poisoning in dermatological treatment

SIR,-We read with interest the article on the successful treatment of a harlequin fetus. ' We note that the baby was initially treated with topical liquid paraffin containing $1 \%$ salicylic acid every three hours. This resulted in significant percutaneous salicylate absorption and systemic toxic manifestations. We have had similar problems with salicylate toxicity after the topical application of salicylate containing preparations for the mangement of skin disorders in two children.

One was an infant born at 38 weeks' gestation and weighing $2500 \mathrm{~g}$. His skin was covered by a collodion like membrane which within 24 hours started to crack and peel in large plaques. Topical $2 \%$ salicylic acid in aqueous cream was applied every three to four hours. On day 3 the baby vomited feeds and had a persistent metabolic acidosis. His salicylate concentration was $3.1 \mathrm{mmol} / \mathrm{l}$. Topical salicylate treatment was stopped and a high fluid intake ensured by intravenous administration. He made a complete recovery.

The second patient was a 12 year old boy with severe icthyosis. Treatment was started with topical $2 \%$ salicylic acid in simple cream applied to the whole body twice daily. The salicylate concentration was increased to $5 \%$ on day 3 of treatment and $10 \%$ on day 5 . On day 8 he developed symptoms of salicylate toxicity. His blood salicylate concentration was $3.3 \mathrm{mmol} / \mathrm{l}$. Topical salicylate treatment was stopped. Intravenous fluids and bicarbonate were given and complete clinical and biochemical recovery was achieved after two days.

Topical salicylate acid in paraffin or simple cream is suggested by several authors as treatment in a number of skin disorders. ${ }^{2-4}$ Our two cases and the one described by Ward and Jones ${ }^{1}$ show that significant percutaneous salicylate absorption can occur not only in newborn infants but also in older children, especially when salicylate preparations of increasing strength are used. We suggest that all topical salicylate treatment should be routinely monitored with salicylate blood concentrations especially during the initial few days after onset or after any changes in treatment.

$P$ GALEA

Royal Hospital for Sick Children, Yorkhill, Glasgow G3 8Sf

1 Ward PS, Jones RD. Successful treatment of a harlequin fetus. Arch Dis Child 1989;64: 1309-10.

2 Roberton NRC. Textbook of neonatology. Edinburgh: Churchill Livingstone, 1986.

3 Forfar JO, Arneil GC. Textbook of paediatrics. Edinburgh: Churchill Livingstone, 1984.

4 Avery GB. Neonatology. Philadelphia: JB Lipincott, 1981 .

\section{Lichen sclerosus}

SIR,-In response to the article on lichen sclerosus by Dr Berth-Jones et al, I would like to take them to task on their quoting 'that there is absolutely no evidence to support any link between lichen sclerosus and sexual abuse. ${ }^{1}$ I disagree that the chances of these two problems occurring together would seem very remote. I have under my care over 400 cases of lichen sclerosus and am well versed in the appearance of lichen sclerosus lesions at sites of trauma-for example, where waist bands and bra straps cause friction. What is more, some patients report extra genital lesions occurring at sites of trauma-for example, oven burns.

It is my feeling that vulval trauma may precipitate vulval lichen sclerosus. I have seen two cases, a girl aged 4 and another aged 6, with definite lichen sclerosus of the vulva and they have also been sexually abused. Another 8 year old girl with a five year history of anogenital lichen sclerosus had also probably been sexually abused at the age of 3 .

It is therefore important to accept that lichen sclerosus does occur at sites of trauma and that the trauma may be sexual abuse.

C I HARRINGTON Glossop Road, Glossop Road,
Sheffield S10 $27 F$ 1 Berth-Jones J, Graham-Brown RAC, Burns DA.
Lichen sclerosus. Arch Dis Child 1989; 64:1204-6.

Drs Berth-Fones, Graham-Brown, and Burns comment:

We are most grateful for Dr Harrington's comments and her important observations. We should be extremely interested to see her patients reported in more detail as they would then be the first properly documented cases in which lichen sclerosus has been found in association with established childhood sexual abuse. In contrast, there are numerous reported examples of lichen sclerosus being misdiagnosed as abuse. In addition to the cases we referred to in our article, it would seem possible that another example occurred in 1987 in Cleveland. ${ }^{1}$ Yet another was reported recently by Jenny et al. ${ }^{2}$

The presence of lichen sclerosus does not exclude the possibility of coincidental sexual abuse, but we were concerned to emphasise that misdiagnosis of lichen sclerosus as sexual abuse is not an uncommon phenomenon.

1 Butler-Sloss E. Report of the inquiry into child abuse in Cleveland 1987. London: HMSO, 1988:134.

2 Jenny C, Kirby P, Fuquay D. Genital lichen sclerosus mistaken for child sexual abuse. Pediatrics 1989;83:597-9.

\section{Lichen sclerosus and sexual abuse}

SIR,-Dr Berth-Jones et al refer to the potential for misdiagnosis of severe anogenital lichen sclerosus as sexual abuse. ${ }^{1}$ They state that 'there is absolutely no evidence to support any link between lichen sclerosus and sexual abuse' and the 'chances of these two problems occurring together would seem very remote indeed'. We wish to report such a case.

We have treated 20 girls aged $4-11$ years with lichen sclerosus over a two and a half year period. One girl, aged $7 \cdot 5$ years, presented with a four month history of intense diurnal frequency of micturition and wetting, and a sore vulva. The appearances were suggestive of early lichen sclerosus with patchy pallor and inflammation, plus minor fusion of the labia minora. Subsequently the changes became much more marked with characteristic thickened sclerotic white plaques, wrinkling, areas of acute inflammation, excoriation, and purpura. Substantial improvement has occurred with topical clobetasone. There have, however, been psychological problems and concern about possible abuse has persisted.
The girl has a complex social background, her stepfather being a schedule I offender (physical injury in a different family). Careful social and psychological investigation initially failed to support a diagnosis of abuse. Over the next year, coincident with worsening of her lichen sclerosus, she developed frequent encopresis, not associated with faecal retention.

She eventually disclosed sexual abuse by her stepfather and much of her story was validated independently by her young brother.

A diagnosis of lichen sclerosus does not exclude sexual abuse, the diagnosis of which, as always, depends more upon statements by the child than upon physical findings. There is the additional possibility that chronic trauma in the presence of low grade skin infection may on occasion lead to the changes of lichen sclerosus

B L PRIESTLEY,
S S BLEEHEN
The Children's Hosptial,
Western Bank,
Sheffield S10 2TH

1 Berth-Jones J, Graham-Brown RAC, Burns DA. Lichen

\section{Fragile $\mathbf{X}$ mental retardation}

SIR,-It is not only in the context of mental retardation without dysmorphic features that the general paediatrician should consider fragile $\mathrm{X}$ syndrome. ${ }^{1}$ It can present as a connective tissue dysfunction which mimics Ehlers-Danlos or Marfan's syndromes ${ }^{2}$ with joint hyperextensibility so severe as to lead to dislocation, high arched palate, and cutis hyperelastica. There may also be mild dysmorphic features such as epicanthic folds and large malformed auricles. Cardiovascular features include mitral valve prolapse and dilatation of the ascending aorta. ${ }^{3}$ We agree that fragile $\mathrm{X}$ is an important diagnosis to exclude, and accept the need to be selective in deciding which patients should be screened, but would suggest that the screening criteria might usefully be broadened to include patients with connective tissue or cardiovascular abnormalities with non-specific developmental delay. We also consider that full cardiological assessment should be performed in proved cases, because of the importance of diagnosing mitral valve prolapse and the need for appropriate prophylaxis against infective endocarditis in these patients.

$$
\begin{array}{r}
\text { A REDINGTON } \\
\text { A BUSH } \\
\text { Department of Paediatric Cardiology, } \\
\text { Brompton Hospital, } \\
\text { Fulham Road, } \\
\text { London SW3 } 6 H P
\end{array}
$$

1 Winter RM. Fragile X mental retardation. Arch Dis Child 1989;64:1223-4.

2 Hagerman RJ, Van Housen K, Smith ACM McGavren L. Consideration of connective tissue dysfunction in the fragile $\mathrm{X}$ syndrome. Am $\mathcal{F}$ Med Genet 1984;17:1111-21.

3 Hagerman RJ. Mitral valve prolapse and aortic dilatation in the fragile $\mathrm{X}$ syndrome. $A m \mathcal{I} M e d$ Genet 1984;17:123-31.

4 Lachman AS, Bramwell-Jones DM, Lakier JB, Pocock WA, Barlow JB. Infective endocarditis in the billowing mitral leaflet syndrome. $\mathrm{Br}$ Heart $f$ 1975;37:326-30.

Fetal ascites: an unusual presentation of Niemann-Pick disease type C

SIR,-We read with interest the paper of Maconochie et al as we have recently seen a case of Niemann-Pick disease type $C$ with an 